\author{
В. І. Носков ${ }^{1}$, В. С. Блиндюк ${ }^{2}$ В. В. Скородєлов ${ }^{1}$, Г. В. Гейко ${ }^{1}$ \\ ${ }^{1}$ Національний технічний університет «Харківський політехнічний інститут», Харків, Україна \\ ${ }^{2}$ Харківський національний університет імені В.Н. Каразіна, Харків, Україна
}

\title{
ПЕРЕВІРКА І НАЛАШТУВАННЯ ПАРАМЕТРІВ ТЯГОВОГО ЕЛЕКТРОПРИВОДУ У СТАЦІОНАРНИХ РЕЖИМАХ
}

\begin{abstract}
Анотація. При розробці електропередачі вітчизняного дизель-поїзда ДЕЛ-02 з тяговими асинхронними двигунами, вирішувалося питання можливості перевірки в умовах депо його основних характеристик. Для цього потрібно було забезпечити в стаціонарних режимах навантаження та контроль роботи дизель-генераторної установки, перетворювача частоти і тягових двигунів без використання додаткового устаткування. Для забезпечення надійності експлуатаційних характеристик дизель-поїзда в систему керування електропередачі введена система контролю і діагностики основних параметрів в процесі руху. Крім того, з урахуванням особливостей схеми електропередачі, передбачена можливість перевірки і налаштування ії параметрів у стаціонарних режимах. Із цією метою запропоновано та обгрунтовано використання гальмового резистора у якості навантаження дизель-генератора, а перетворювач частоти при цьому навантажується на загальмовані тягові двигуни. При цьому система регулювання залишається замкнутою, а реєстрація параметрів виконується системою контролю і діагностики.
\end{abstract}

Кл юч о в і сл ов а: тяговий асинхронний двигун, дизель-поїзд, система контролю і діагностики, гальмовий резистор.

\section{Вступ}

Ефективність перевезень залізничним транспортом у першу чергу залежить від надійності його роботи. Для забезпечення надійності роботи локомотива в його схему керування складовою частиною вводиться система контролю і діагностики, яка видає машиністу оперативну інформацію про роботу його основних складових: дизеля, електропередачі, системи керування та ін. У той же час потрібно перевіряти i, при необхідності, налаштовувати характеристики локомотива в стаціонарних режимах. Особливістю схеми електропередачі дизель-поїзда ДЕЛ-02 є наявність електричного гальмування, що дозволяє здійснювати перевірку характеристик дизель-генератора навантаженням на гальмовий резистор без використання додаткового устаткування.

Аналіз літератури. Виконання систем регулювання електропередачею із використанням сучасних засобів мікропроцесорної техніки та мікроЕОМ дає можливість реалізувати як ефективне керування, так і контроль роботи устаткування при експлуатації [1-4]. Основна увага авторів приділяється питанням створення бортових систем контролю і діагностики, які забезпечують машиніста необхідною інформацією про роботу основних елементів локомотива, а також автоматизованим системам 3 дистанційним контролем окремих вузлів локомотива при його русі по перегону. У той же час, питанню стаціонарної перевірки технічного стану локомотива не приділено належної уваги, особливо для автономних локомотивів із сучасним тяговим асинхронним приводом $[5,6]$.

В статті розглядається питання перевірки, а, при необхідності, налаштування характеристик тягової електропередачі дизель-поїзда ДЕЛ-02 у стаціонарних режимах без використання додаткового устаткування. Для досягнення цієї мети було проведено:

- аналіз схеми електропередачі з урахуванням реалізації необхідних режимів роботи;

- розгляд можливого використання системи регулювання та системи контролю і діагностики (СКД);
- розробку методів перевірки характеристик тягової електропередачі та якості роботи системи автоматичного регулювання (САР) без використання додаткового устаткування.

\section{Основна частина}

В процесі експлуатації параметри автономних локомотивів можуть відхилятися від необхідних значень, що негативно позначається на їх технічних i економічних показниках. У зв'язку із цим, в умовах депо необхідно мати можливість їхнього контролю, відновлення і налаштування [6-8]. При наявності в депо водяного реостата, перевірка дизель-генератора виконується його навантаженням через штатну випрямну установку локомотива на реостат.

Реостат являє собою бак, наповнений водою, у який опущені рухомі та нерухомі електроди (пластини). До рухомих і нерухомих електродів приєднані силові кабелі від випрямної установки локомотива. Величина опору реостата залежить від ступеня занурення у воду рухомих пластин, що дозволяє виконати контроль i, при необхідності, налаштувати на відповідність технічним вимогам селективну (1) і зовнішню (2) характеристики генератора (рис. 1) з обмеженнями по струму (А), напрузі (B) і потужності (C). Селективна характеристика відповідає потужності, яка відбирається від дизель-генератора на тягу, без обліку потужності допоміжних навантажень і опалення салонів вагонів (якщо воно є). Зовнішня характеристика - це повна потужність, яку розвиває дизель на конкретній позиції контролера машиніста (КМ). Структурна схема електропередачі моторного вагона дизель-поїзда ДЕЛ-02 наведена на рис. 2. Тяговий генератор, що обертається від дизеля, через випрямну установку (ВУ) і автономні інвертори напруги (AIH1, AIH2) живить тягові асинхронні двигуни (ТАД1, ТАД2). Особливістю цієї схеми є те, що від тягового генератора через ВУ та перетворювачі частоти власних потреб (ПЧВП) живляться всі допоміжні споживачі, у тому числі й опалення вагонів. При цьому їх сумарна споживана потужність становить 45 кВт. 


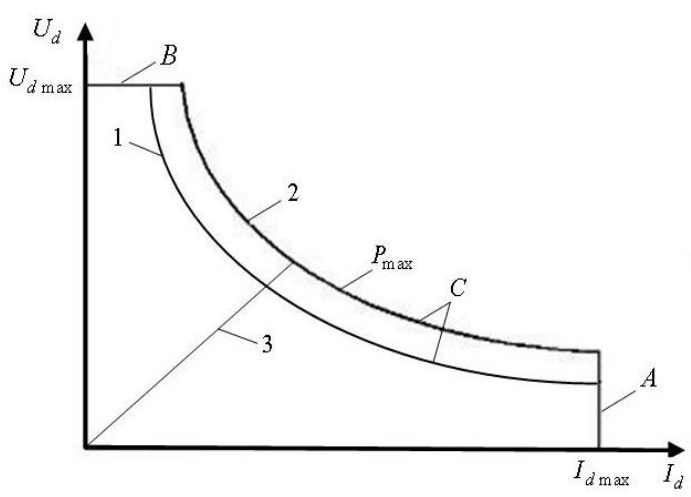

Рис. 1. Характеристики генератора $\left(U_{d}, I_{d}\right.$, $\mathrm{P}$ - випрямлена напруга, струм і потужність генератора)

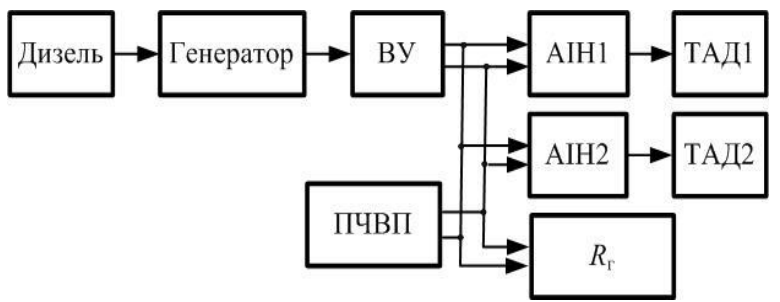

Рис. 2. Структурна схема електропередачі моторного вагона дизель-поїзда ДЕЛ-02

При електричному гальмуванні ТАД працюють у режимі генераторів і через AIH1 та AIH2 навантажуються на гальмовий резистор $\mathrm{R}_{\Gamma}$, тяговий генератор відключається від ланцюга постійної напруги випрямлячем ВУ, вентилі якого заперті зворотною напругою на ньому. На дизель-поїзді застосовано дизель 3 електронним регулятором. Універсальна характеристика дизеля наведена на рис. 3.

Тяговий генератор являє собою синхронну електричну машину 3 незалежним збудником, що має дві трифазні статорні обмотки, від яких через випрямляч одержують живлення тягові інвертори, перетворювачі власних потреб і система опалення вагонів. ТАД - це трифазна асинхронна реверсивна електрична машина 3 короткозамкненим ротором. Завдання збудника тягового генератора і регулювання режимами роботи електропередачі здійснюється мікропроцесорною системою [9].

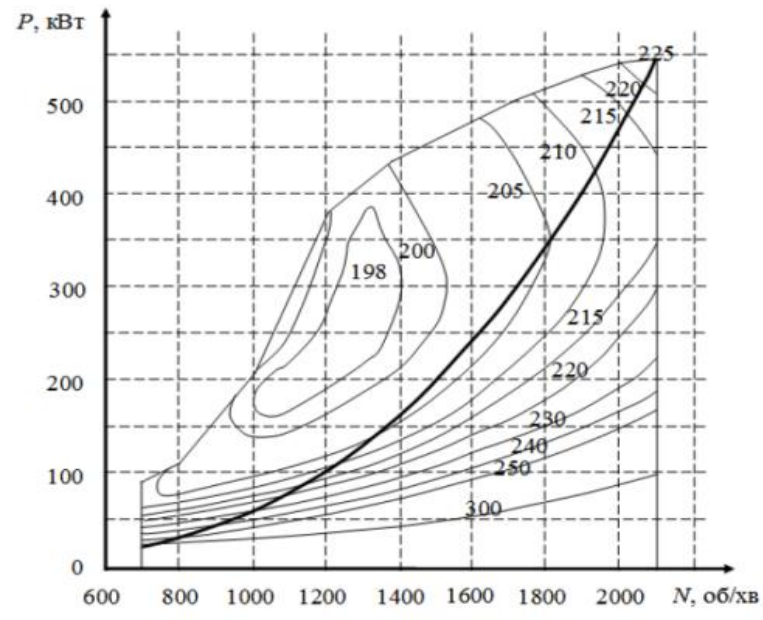

Рис. 3. Універсальна характеристика дизеля $12 \mathrm{~V} 183 \mathrm{TDB}$
Функціональна схема системи регулювання i контролю параметрів моторного вагона дизельпоїзда ДЕЛ-02 наведена на рис. 4.

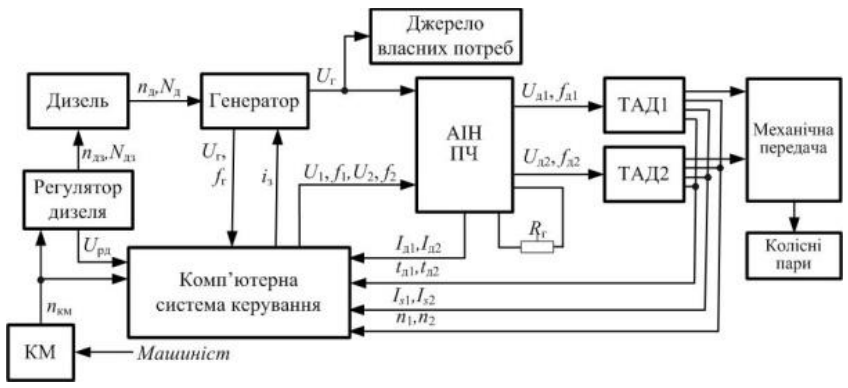

Рис. 4. Функціональна схема системи регулювання і контролю параметрів моторного вагона дизель-поїзда ДЕЛ-02

На рис. 4 приведені такі позначення: КМ - контролер машиніста; ПЧ - перетворювач частоти; $n_{\kappa м}$ - номер позиції контролера машиніста; $n_{\partial 3}$, $N_{\partial з}-$ сигнали завдання частоти обертання та потужності дизеля; $n_{\partial}, N_{\partial}$ - вихідні частота обертання та потужність дизеля; $U_{p \partial}-$ коригуючий сигнал потужності дизеля; $U_{2}, f_{2}$ - напруга і частота генератора; $i_{3}$ - струм збудження генератора; $U_{1}, U_{2}$, $f_{1}, f_{2}$ - завдання параметрів ПЧ; $f_{\partial 1}, f_{\partial 2}, U_{\partial 1}$, $U_{\partial 2}$ - частоти та напруги живлення ТАД1 і ТАД2; $I_{\partial 1}, \quad I_{\partial 2}$ - значення активного струму ТАД1 і ТАД2; $t_{\partial 1}, t_{\partial 2}$ - температура ТАД1 і ТАД2; $n_{l}$, $n_{2}$ - частоти обертання роторів ТАД1 і ТАД2; $I_{s 1}$, $I_{s 2}-$ значення повного струму ТАД1 і ТАД2.

Перевірці підлягають: дизель-генератор, перетворювач частоти, тягові асинхронні двигуни і система регулювання електропередачі. Оскільки на дизель-поїзді реалізована система електричного гальмування, при якій гальмова потужність розсіюється на гальмовому резисторі, це дозволяє виконати перевірку характеристик дизель-генератора навантаженням через штатний випрямляч на гальмовий резистор при повній потужності дизеля без використання водяного реостата.

Схема включення гальмового резистора при навантаженні дизель-генератора наведена на рис. 5. При цьому тягові інвертори відключаються від випрямляча. Сигнали 3 вимірювальних шунтів, які пропорційні випрямленому струму навантаження генератора, надходять у схему регулювання контролю і діагностики.

У зв'язку з тим, що величина гальмового резистора незмінна, характеристики $U_{d}=f\left(I_{d}\right)$ або $P=U_{d} \cdot I_{d}$ по позиціях КМ мають вигляд прямої лінії 3 (рис. 1). Вимірювана потужність повинна відповідати необхідній відповідно до універсальної характеристики дизеля. До складу мікропроцесорної системи керування входить СКД [9], що істотно спрощує виконання цієї роботи, тому що всі основні параметри електропередачі виведені на екран 
комп'ютера як у цифровому виді, так і у вигляді осцилограм. Якість роботи дизель-генераторної установки варто розглядати в цілому, з огляду на той факт, що системи регулювання дизеля і генератора мають безпосередні зв'язки і взаємний вплив. Електронний регулятор дизеля забезпечує підтримку заданої частоти обертання і потужності по позиціях КМ при змінних умовах навантаження, крім того, визначає і видає зовнішній сигнал про ступінь завантаження дизеля (сигнал неузгодженості потужності). САР тягового генератора (рис. 6) виконана по комбінованому принципу: замкнута САР по відхиленню доповнена регулюванням по збуренню.

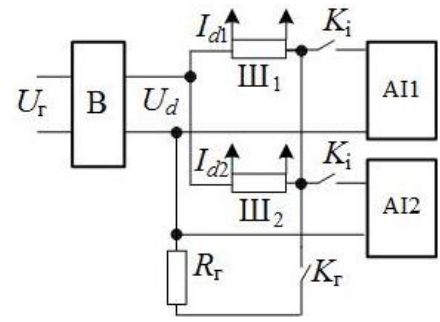

Рис. 5. Схема навантаження дизель-генератора на гальмовий резистор (В - випрямляч, $U_{d}$ - випрямлена напруга генератора, AI1, AI2 - автономні інвертори, $K_{2}, K_{i}$ - контактори, $U_{1}, U_{2}$ - вимірювальні шунти, $U_{2}$ - напруга генерато$\mathrm{pa}, I_{d}$ - струм навантаження на резисторі)

Сигнал завдання е нератора формується як функція обертів дизеля е (позиції КМ), а його коригування здійснюється сигналом неузгодженості потужності від регулятора дизеля $\left(\mathrm{e}_{\text {рд }}\right)$ і сигналом включення допоміжних навантажень і опалення $\left(\mathrm{e}_{\text {сн }}\right)$ :

$$
e_{3}=e_{i} \pm e_{p \partial} \pm e_{C H} .
$$

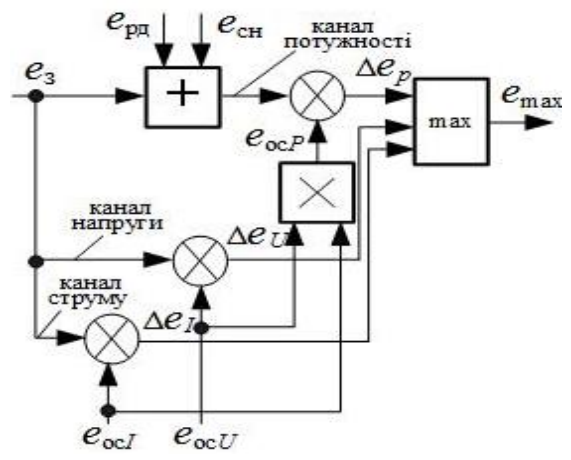

Рис. 6. Схема формування характеристик дизель-генератора

Застосування комбінованого принципу регулювання забезпечує його високу якість і повне використання потужності дизеля відповідно до його характеристик. У табл. 1 наведені результати навантаження дизель-генератора на гальмовий резистор моторного вагона дизель-поїзда ДЕЛ-02 у моторвагонному депо «Христинівка» регіональної філії «Одеська залізниця».

Як видно $з$ табл. 1 , характеристика $P_{2}=f(n)$ повністю відповідає необхідним значенням на всіх позиціях КМ, що підтверджується вихідним сигналом регулятора дизеля, який дорівнює 5 В.

Таблиия 1-Результати навантаження дизель-генератора на гальмовий резистор моторного вагона дизель-поїзда ДЕЛ-02 у моторвагонному депо «Христинівка» регіональної філії «Одеська залізниця»

\begin{tabular}{|l|c|c|c|c|c|c|c|c|c|}
\hline № позиції КМ & $\mathbf{0}$ & $\mathbf{1}$ & $\mathbf{2}$ & $\mathbf{3}$ & $\mathbf{4}$ & $\mathbf{5}$ & $\mathbf{6}$ & $\mathbf{7}$ & $\mathbf{8}$ \\
\hline Обороти дизеля, об/хвил. & 800 & 800 & 1000 & 1200 & 1400 & 1600 & 1800 & 2000 & 2100 \\
\hline Потужність СГ,Рг, кВт & 68,5 & 72 & 129 & 191,7 & 250 & 330 & 381 & 441 & 462,3 \\
\hline Сигнал регулятора дизеля, ерд, В & 5,0 & 5,0 & 5,0 & 5,0 & 5,0 & 5,0 & 5,0 & 5,0 & 5,0 \\
\hline
\end{tabular}

Відхилення від значення 5 В означають невідповідність потужності дизеля його оптимальному значенню на конкретній позиції КМ. Перевірка якості роботи перетворювача частоти і ТАД у замкнутій САР виконується на загальмованому локомотиві. При рушанні з місця і розгоні, електропередача забезпечує сталість тягового зусилля, тобто тягові двигуни працюють із постійним моментом (рис. 7).

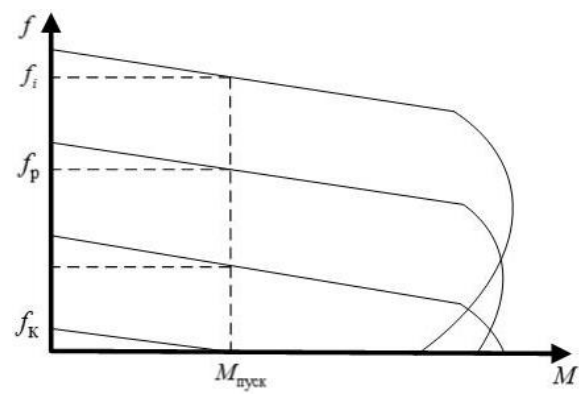

Рис. 7. Механічні характеристики ТАД при рушанні

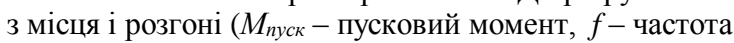
живлячої напруги, $f_{1}$ - частота, пропорційна частоті обертання ротора, $f_{k}=f_{i}-f_{p}$ - частота ковзання ротора)
Оскільки ТАД нерухомий, тобто $f=f_{\kappa}$, можна користуватися його статичними характеристиками, вважаючи, що:

$$
M \equiv I \cdot \Phi,
$$

де I - струм фази, $\Phi=E / f-$ магнітний потік ТАД.

Задаючи розрахункове значення $f=f_{\kappa}$, САР підтримує постійною задану величину струму і магнітного потоку, залежно від позиції КМ, тобто забезпечує необхідне тягове зусилля дизель-поїзда при рушанні з місця. За формою фазних струмів i напруги на виході ПЧ можна зробити висновок про справність ПЧ і ТАД, а в цілому - по якості роботи тягового електропривода [10].

На рис. 8 наведена осцилограма фазного струму тягового двигуна в «стоповому» режимі при частоті живлячої напруги 0,5 Гц і процес включення електропередачі в режимі тяги.

Крім того, при статичних випробуваннях можна перевірити i, при необхідності, налаштувати захист електропередачі від перевищення значення його параметрів. 


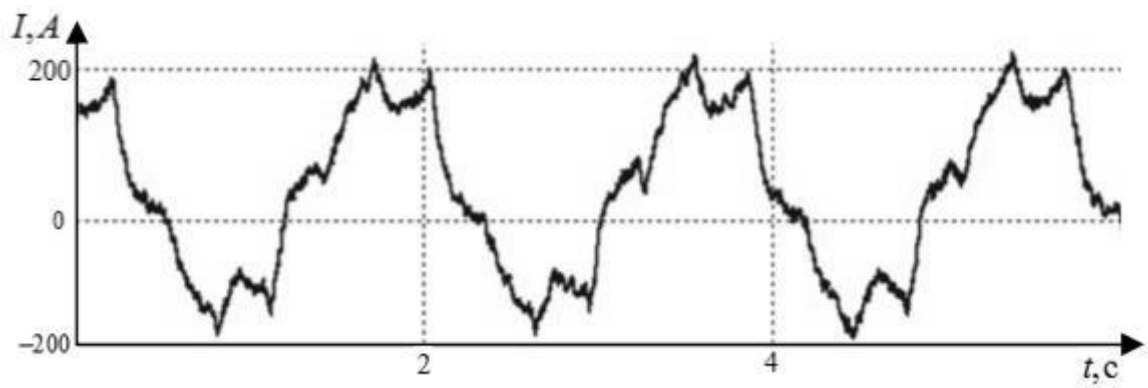

Рис. 8. Осцилограма фазного струму ТАД при загальмованому двигуні

Розроблений метод перевірки характеристик тягової електропередачі використовується при експлуатації дизель-поїздів ДЕЛ-02 на Одеській залізниці.

\section{Висновки}

Проведено аналіз схеми електропередачі дизель-поїзда ДЕЛ-02 з урахуванням його характеристик при роботі в режимі тяги та електричного гальмування, а також реалізація системи автоматичного регулювання і системи контролю і діагностики.
Результати аналізу дозволили розробити метод перевірки характеристик тягової електропередачі та якості роботи САР у стаціонарних режимах без використання додаткового устаткування. Запропоновано виконувати перевірку характеристик дизель-генератора навантаженням його на гальмовий резистор, а перетворювачі частоти і ТАД - при загальмованих тягових двигунах. При всіх випробуваннях використовується замкнута САР електропривода, а контроль параметрів здійснюється за допомогою СКД.

\section{СПИСОК ЛІТЕРАТУРИ}

1. Боднар Є.Б. Основні вимоги та принципи створення бортових систем діагностування локомотивів / Є.Б. Боднар. Наука та прогрес транспорту. 2014. - № 1 (49). - С. 68 - 74.

2. Мельников В. Диагностирование тепловозов по данным бортовых микропроцессорных систем / В. Мельников // Мир транспорта. - № 3, 2014. - С. 56 - 60.

3. Нургулжанова А.Н. Анализ систем диагностики технического состояния локомотивов и вагонов при движении железнодорожных составов / А.Н. Нургулжанова, Э.А. Багыбаева // Материалы XLI Межд. НПК. КазАТК им. М. Тынышпаева «Инновационные технологии на транспорте: образование, наука, практика». - Т.2, 2017. - С. 169 - 171.

4. Бабков Ю. Многофункциональная микропроцессорная система управления тепловозом / Ю. Бабков и др. - Железнодорожный транспорт. СТА № 3, 2004. - С. 46 - 52.

5. Басов Г.Г. Розвиток електричного моторвагонного рухомого складу. Ч. 1. / Г.Г. Басов, С.І. Яцько. - Харків: Апекс+, 2005. $-248 \mathrm{c}$.

6. Белоглазов А.К. Оценка эффективности работы дизель-генераторных установок по результатам контроля параметров при проведении реостатных испытаний / А.К. Белоглазов и др. // Известия Транссиба / Омский гос. ун-т путей сообщения. - Омск. - 2017. - № 2 (30). - С. 2 - 8.

7. Тарута В.Ф. Технология контроля уровня мощности для настройки дизель-генераторной установки маневрового тепловоза с учетом условий эксплуатации / В.Ф. Тарута. А.В. Чулков, Л.В. Милютина // Известия Трансиба / Омский гос. ун-т путей сообщения. - Омск. - 2018. - № 1 (33). - С. $109-117$.

8. Данковцев В.Т. Техническое обслуживание и ремонт локомотивов / В.Т. Данковцев, В.И. Киселев, В.А. Четвергов / УМЦ ЖДТ. - М., 2007. - 557 с.

9. Носков В.І. Контроль і діагностика стану тягового електропривода / В.І. Носков, М.В. Мезенцев, С.Ю. Гавриленко, Г.В. Гейко // Системи управління, навігації та зв'язку. - Полтава: Національний університет «Полтавська політехніка імені Юрія Кондратюка». - вип. 1 (63). - 2021. - С. 58 - 61.

10. Носков В.И. Метод определения гармонического состава фазного тока статора асинхронного двигателя в системах регулируемых приводов / В.И. Носков, Н.В. Мезенцев, Г.В. Гейко, М.В. Липчанский // Системи обробки інформації: збірник наукових праць. - Харків: ХУПС, 2015. - № 7 (132). - С. 59 - 61.

Received (Надійшла) 26.05.2021

Accepted for publication (Прийнята до друку) 04.08.2021

\section{Checking and adjusting parameters of traction electric drive in stationary modes Valentin Noskov, Vasyl Blyndiuk, Volodymyr Skorodielov, Hennadii Heiko}

Abstract. When developing the power transmission of the domestic diesel train DEL-02 with traction asynchronous motors, the question of the possibility of checking its main characteristics in the conditions of the depot was decided. To do this, it was necessary to provide in stationary load condition and control of the operation of the diesel generator set, frequency converter and traction motors without the use of additional equipment. To ensure the reliability of the operational characteristics of the diesel train, a system for monitoring and diagnosing the main parameters in the process of movement has been introduced into the power transmission control system. In addition, taking into account the peculiarities of the power transmission, it is possible to check and adjust its parameters in stationary modes. For this purpose, it has been proposed and justified to use a braking resistor as a load of a diesel generator, while the frequency converter is loaded onto the braked traction motors. In this case, the control system remains closed, and the registration of parameters is performed by the monitoring and diagnostic system.

Keywords : traction asynchronous motor, diesel train, monitoring and diagnostic system, braking resistor. 